International Journal of Instruction e-ISSN: 1308-1470 • www.e-iji.net
July $2018 \bullet$ Vol.11, No.3

p-ISSN: 1694-609X

pp. 219-232

Received: 02/11/2017

Revision: 03/03/2018

Accepted: 10/03/2018

\title{
The Effect of Learning Styles on Academic Achievement in Different Forms of Teaching
}

\author{
Ivana Cimermanová \\ University of Presov, Slovakia, ivana.cimermanova@unipo.sk
}

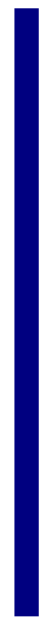

In recent years, researchers have shown an increased interest in learner styles as one of the key factors influencing learning generally. During the last decade we have also noticed rapid advances in the field of technology enhanced learning and growing trend towards its application in formal education. Introduction of different forms of e-learning (e.g. computer assisted learning, blended learning, massive online open courses (MOOCs), etc.) has become reality at most universities. The principal objective of the research presented in the study was to find out whether learning styles of students and the form of teaching generate interaction effects on their learning achievements. Grasha-Riechmann Student Learning Style Scales (GRSLSS) inventory was applied to define the learner styles of the sample subjects and pedagogical quasi experiment was conducted within the period of one semester. The research used a convenience sample of 81 fifth year university students (pre-service English language teachers) split into control $(\mathrm{n}=55)$ and experimental $(n=27)$ groups. The results of a two-way analysis of variance (ANOVA) showed no significant findings. The results indicate that the learning styles and form of teaching have no effect on academic achievement.

Keywords: learner style, technology enhanced language learning, e-learning, experiment, language learning

\section{INTRODUCTION}

In the last few decades, there has been a surge of interest in the effects of learning styles in education what also resulted in various criteria and categorizations of learning styles. Different categorization or models are based on e.g. sensory input (Flemming's VA(R)K model, see e.g. Flemming\& Mills (1992)), grasping knowledge (Kolb's model, see e.g. Kolb (2015)), approach to learning (Entwistle, et al. (2001); Riechmann and Grasha (1974)) etc. The theory of learning styles received considerable critical attention. A deep analytical and critical review was published by Coffield, et al. (2004). They fully analysed 3800 references and in their evaluation they also postulated recommendations which models are appropriate for certain situations and different target groups. They presented both, researchers supporting the idea of learning styles theories as well as the

Citation: Cimermanová, I. (2018). The Effect of Learning Styles on Academic Achievement in Different Forms of Teaching. International Journal of Instruction, 11(3), 219-232. https://doi.org/10.12973/iji.2018.11316a 
opponents "who espouse qualitative rather than quantitative research methods, dispute the objectivity of the test scores derived from the instruments" (p. 127). The opponents claim, e.g., that the measurements are based on the subjective judgements which respondents make about themselves. Based on the facts that research into learning styles consists of wide variety of approaches and researchers work in isolation Coffield et al. (2004) characterise it as "small-scale, non-cumulative, uncritical and inward-looking". In their study they also clearly formulate there is "widespread disagreement about the advice that should be offered" to teachers. Still, they claim that a "reliable and valid instrument which measures learning styles and approaches could be used as a tool to encourage self-development, not only by diagnosing how people learn, but by showing them how to enhance their learning" (p.136).

In the present study we used GrashaRiechman learning style model as it identifies the preferences in interacting with other learners, peers and teachers; it reflects the learners' abilities and preference to work independently, preferences to cooperate or to compete to become a participant or avoidant in a virtual learning environment. Electronic education has its own specifics and characteristics. The interactions in the virtual learning environment (VLE) have to be carefully pre-planned. As soon as in planning phase it must be considered that learner's willingness to cooperate and collaborate must be catered systematically. The present research examined the possible relation between the learning style of the learners, the formof teaching and the academic achievement of the students. We assumed that the form (in-class or online) and learning styles do not influence the academic performance of students. The assumption was based on the fact that the content is the same, the students voluntarily opted to take the certain form and had considered their learning preferences and the advantages the different forms offered (direct contact, set time, regularity, place, immediate feedback vs virtual contact, deadlines, but not the particular time of learning, possible delayed feedback etc.).

\section{THEORETICAL FRAMEWORK}

Prensky (2010, p. 23) states that “Today's students will not live in a world where things change relatively slowly (as many of us did) but rather in a future where things change extremely rapidly - daily and exponentially. So, today's teachers need to be sure that, no matter what subject they are teaching, they are teaching it with that future in mind".

In the period when we face massification of higher education, globalisation, penetration of technologies into everyday life and education and their availability and accessibility it has to have the influence on the assumptions about learning. Benson and Brack (2010) transferred the old conventions (applied in behaviourist approach) to new constructivist assumptions. Learning is from the constructivist viewpoint "conceptualised as an active process in which learners construct new ideas or concepts based upon their own knowledge, both old (from the past) and new. Learning is seen as occurring best when it is situated in authentic contexts. Hence, problem-based and case-based learning are founded on constructivist ideas" (ibid, p. 3). Social constructivism emphasizes the collaborative nature of learning. It is a variety of cognitive constructivism. Generally, the philosophy of constructivism highlights and stresses the importance of social interaction in building (constructing) knowledge. Individual learning needs an 
independent autonomous learner who is ready to apply different learning strategies effectively; and individual learning is essential to develop teamwork and collaboration skills. At the same time to build a community the participants must collaborate and cooperate.

A considerable amount of literature has been published on different forms of teaching its organization, teaching methods and techniques. Technology enhanced learning has become a regular part in teaching practice in many higher education institutions. This naturally led to conducting research on its use, methodology, interaction (Watts, 2010; Chickering\&Gamson, 1989), activities (Salmon, 2000; MacKenzie\& Ballard, 2015), different tools (Lehman \&Conceição, 2010), software development, VLEs (Weller, 2007), effectiveness (Nguyen, 2015). Conrad \& Donaldson (2004, p. 4) state that: "Bruner, Vygotsky, and Piaget all embraced the philosophy that humans do not learn in a vacuum but rather through interaction". Various studies report the positive effect of interaction on the increase in the educational effectiveness and promotes deeper learning (Mayer \& Chandler, 2001; York \& Richardson, 2012; Tsai, 2011).

As it has been mentioned, it is important to build a positive and supportive atmosphere. Considering the learners, especially if they are in new environment (both - new technology and new group) we have to satisfy their needs, especially the safety needs, love needs and esteem needs. Conrad and Donaldson (2004) discuss an engagement of teacher and students in e-course and they identify 4 phases in which learners' and teachers' roles differ. The first, initial phase (they name it Phase 1) is very important as the attitudes are formed especially in this phase. A learner is in the role of newcomer and teacher usually provides "socialising activities" to help learners to know each other and to help them to get oriented in a VLE and course itself (ice-breakers, (threaded) discussions about community issues. Palloff and Pratt (2007, In: Lehman, Conceição, 2010 , p. 8) "consider social presence to be a critical element in online community building". The way students participate and contribute to the educational process is influenced by various factors (motivation, aptitude, attitude, age, etc.). The learner style as one of the factors that may influence the success of the educational process have been studied by number of researchers (Chen et al., 2015; Kamuche, 2011; Wilkinson, Boohan\& Stevenson, 2013; Kaminski, et al., 2005). Kaminiski, et al. (2005) applied Kolb's Learning Style Inventory and found a significant level of relation between grades and learning style. They divided students to dominant and non-dominant and report that "looking at the dominant learner, the majority of highest grades are awarded to convergers" (p. 10.508.11). Wilkinson, et al. (2013) applied Honey and Mumford's Learning Style Questionnaire (LSQ) that is derived from Kolb's experiential learning cycle. In a group of 260 university students with the reflector dominant learning style they have "not found strong evidence of learning styles influencing examination results" (p. 308). Fleming, et al. (2011) ran a longitudinal research and in their study they claim that 'learning style is not a fixed trait. Most students' individual learning style changed over the two time points with the greatest improvement occurring in the Activist learning style" (p. 448). 
Learner styles are characteristics that are considered especially in selecting the most appropriate methods, techniques and learning strategies. Usually people possess more than one style (does not matter which categorization or classification is considered), they have "profile of styles" (Biggs, 2011, p. 79) even though there are usually one or more dominant ones (Gardner, 2011; Sternberg, Zhang, 2011; Prextová, 2016). In case of bigger classes one normally teaches learners with different styles and thus it would be not appropriate to rigidly apply the methods for the selected type.

Dille\&Mezack (1991) conducted research with the aim to identify predictors of high risk for students in telecourses. Based on the premise that web-based learning leads to social isolation and students are expected to be independent and autonomous, they applied Kolb's Learning Style Inventory to measure student learning style preference. Dille\&Mezack (ibid) reported that students who were not able to think abstractly and relied on concrete experience were at more high risk. Virtual learning environment (VLE) and technologies applied today allow different tools for socialization and also the visualization of material and different types of interaction (Weller, 2007; Palloff\& Pratt 2007; Russell, 2010).

In the present research we applied Riechmann Student Learning Style Scales to identify the learners' styles. Their classification is based on three pairs of dichotomies that classify learners based on their social interaction, namely competitive-collaborative; avoidant-participant; dependent-independent. Collaborative learners are ready to share ideas, prefer group or pair work rather than individual work what is the preferred interaction pattern of competitive learner. Those like to be in the center and communicate rather with the teachers than peers. Avoidants on the other hand do not want to communicate neither with the peers nor with the teacher. They are not interested in the content or activities performed in the class and are not motivated to take part in them. Their dichotomic pair is a participant, a learner who is eager to help everybody and to do more than expected even without being noticed and overpraised. The last pair of learner styles is dependent and independent and simply can be characterized as those who learn what they have to and what they are said to (dependent) or students intrinsically motivated, autonomous learners who are ready to work on their own. Grasha (2002) claims the learner styles should be understood as certain preferences that occur or do not occur in particular situations. This might be explained that learners act differently and apply different styles in particular, different situation. What is important to say is that "While learners generally prefer certain styles, this preference can and often does change depending upon how the teacher structures the class" (Grasha, 2002, p. 171). These facts have to be carefully considered in planning teaching as they have direct impact on the results of educational activities. Speaking about the possibility to apply online or in-class courses Diaz \&Cartnal (1999) stress that in case learning is dependent on learning style and these styles vary between online and in-class students then teachers should be aware of it and adjust their teaching and instructional methods accordingly. Grasha (ibid, p. 172) speaks about three options teachers have in planning the lessons dealing with learner styles. They can design their instruction to accommodate particular/prevailing styles; they can prepare their lessons to provide mismatches in the prevailing styles learners possess or they can apply different 
processes "so that students are exposed to methods that accommodate as well as provide "creative mismatches" with their preferred learning styles". There are studies published that have indicated that there is relation of style and gender (Amira \&Jelas, 2010; Halili et al., 2014). Also the relation of the field and style was observed (Hamidah et al., 2009). In this sense the sample of the present study can be understood as limitation for generalisation of the results.

\section{PURPOSE OF THE STUDY}

As already mentioned, the major objective of the study was to examine the possible relation between the preferred learning style, the form of teaching and the students' performance in the course. To this end, we needed the valid instrument to measure styles. The Grasha-Riechmann Student Learning Style Scales (GRSLSS) inventory was applied in the study. To formulate the research question we state: Do the learning styles of students and the form of teaching generate interaction effects on their learning achievements? We state the following:

- Interaction effect hypothesis

H01: Students with different learning styles do not statistically significantly differ in their academic performance based on the form of their study,

- Main effect hypotheses:

H02: Students with different learning styles do not statistically significantly differ in their academic performance

H03: In-class and online students do not statistically significantly differ in their academic performance.

\section{METHOD}

The research was realised during the period of one semester - 13 weeks and the main research tool was pedagogical experiment $(n=82)$ with two groups - online (experimental) group and in-class (control) group. For the purpose of experiment control group students were enrolled to learning management system (LMS) Moodle and the other groups had traditional face-to-face in-class lessons where the number of lessons, aims and content were same. The difference was the delivery of the material (both content provided by the teacher and assignments delivered by students) and the way of communication (chat used as a tool for synchronous communication and forum used for asynchronous communication).

\section{Sample description}

The cohort was divided into 2 groups - experimental $(n=27)$ and control groups $(n=55)$. All participants were 5th year pre-service English language teachers at the University of Presov aged 21-26. EFL methodology was a compulsory subject for all of them and they could voluntarily opt to take the in-class or online alternative of the course. Concerning the students (their characteristics and needs) it should be stated that at the time of experiment they had already passed general teacher training, they realised the responsibility of the teacher and the class participation as necessary factors that have impact on the didactic efficiency of the process. 


\section{Instrument and procedure}

It has been mentioned that The Grasha-Riechmann Student Learning Style Scales (GRSLSS) inventory was applied in the study. The inventory consists of 60 items (10 items per category) using a five-point rating scale that ranges from strongly disagree (rating of 1) to strongly agree (rating of 5). The students filled the inventory in before the intervention at the beginning of the semester. They could voluntarily decide which group they prefer to study the course on Methodology in (there was a limit of maximum 30 students per VLE/control group). The rest of sample was divided into two groups that had classes separately. The research was realised during their third semester (each semester finished by the exam).

To check the efficiency of the course in VLE (virtual learning environment) and in inclass setting (face-to-face) the pre-test results and the results of the final knowledge test (post-test) were compared. The pass grade at the university is expressed in per cents and is set to $50 \%$, students' achievement was measured by their cumulative grade in knowledge exam (range 1 to 100, number of retakes was not considered).

\section{Data analysis}

Before statistical analyses, data screening was performed using IBM SPSS 23. A total of four variables, including learning style, form, pre-test score and post-test score, were examined. There was no statistical difference in the results students reached in the exam before the intervention (all students had the classes in-class). The results of the GRSLSS were analysed and the results of the independent and dependent learning style were very similar (it can be also seen in fig. 1). The most dominant and preferred style in in-class group was collaborative $\left(\mathrm{x}^{-}=3,97 ; \mathrm{SD}=0,78\right)$, the least preferred was avoidant $\left(\mathrm{x}^{-}=1,99\right.$; $\mathrm{SD}=0,49)$. In the online group the most preferred style was independent $\left(\mathrm{x}^{-}=3,55\right.$; $\mathrm{SD}=0,72)$ and the least preferred was competitive $\left(\mathrm{x}^{-}=1,98 ; \mathrm{SD}=0,78\right)$. 


\section{FINDINGS}

\section{Figure 1}

Average scores for learning styles

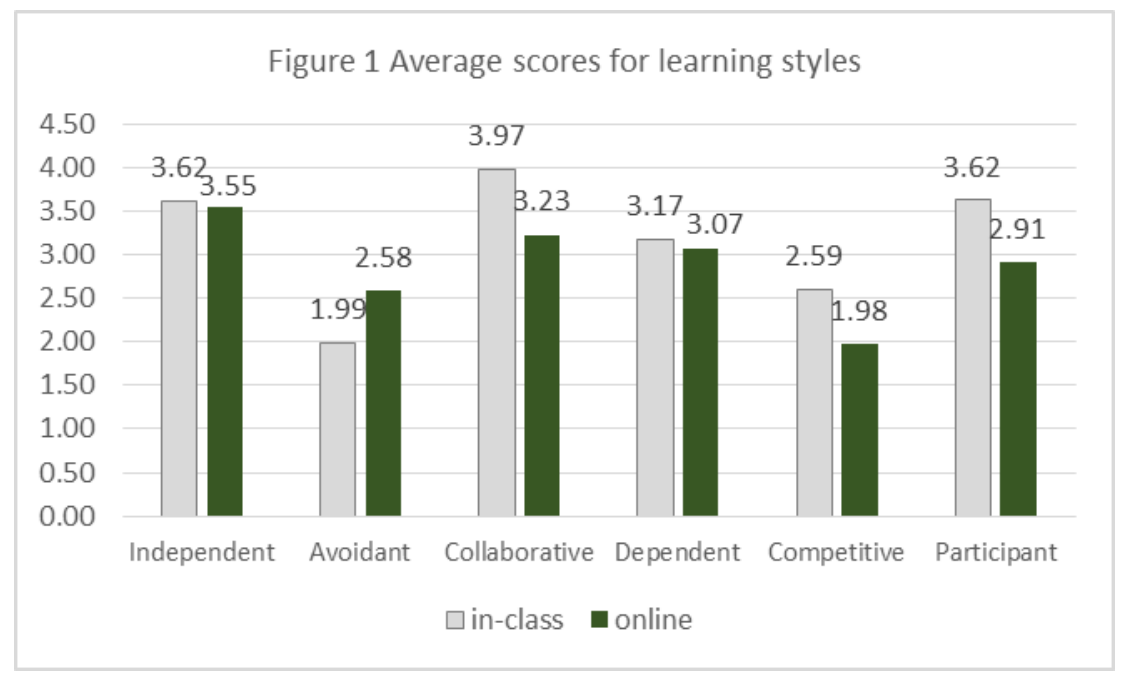

We conducted a two-way ANOVA test to determine if there was an interaction effect of learning style and form (in-class, online) on learning achievement. The dependant variable was the academic achievement (evaluation 2). The two independent variables presented the six learning styles (independent, avoidant, collaborative, dependent, competitive, participant) and two forms (online and in-class).

For the form, the ANOVA result (table 1) indicated no significant interaction, $\mathrm{F}(1,72)=$ $.27, \mathrm{p}>.05$. Similarly, no interaction effect was recorded for learning style, $F(4,72)=$ $.06, \mathrm{p}>05$. No significant interaction effect was found when learning style was the dependent variable and form and evaluation were the independent variables.

Table 1

F-ratio of the two-way ANOVA analysis for interaction between form and learning style on the academic achievement

\begin{tabular}{|llllll}
\hline Source & Type III Sum of Squares & df & Mean Square & F & Sig. \\
\hline Corrected Model & $2142,822^{\mathrm{a}}$ & 9 & 238,091 & 1,626 &, 124 \\
Intercept & 173176,361 & 1 & 173176,361 & 1182,4 &, 000 \\
& 183,246 & 1 & 183,246 & 1,251 &, 267 \\
form & 1373,386 & 4 & 343,346 & 2,344 &, 063 \\
GRS & 635,858 & 4 & 158,965 & 1,085 &, 370 \\
form * GRS & 10545,190 & 72 & 146,461 & & \\
Error & 549233,000 & 82 & & & \\
Total & 12688,012 & 81 & & & \\
Corrected Total & S & & & & \\
\hline
\end{tabular}

a. R Squared =,169 (Adjusted R Squared $=, 065$ ) 
A Pearson correlation analysis was conducted in order to assess the strength of the possible correlation of the learning style associated with the academic achievement (academic achievement (post-test)). Significant correlation emerged only between competitive learning style and academic achievement in an online group. The results of the correlational analysis are displayed in Table 2.

Table 2

Correlations of the learning styles and evaluation

\begin{tabular}{|c|c|c|c|c|c|c|c|c|}
\hline Form & & & $\begin{array}{l}\overrightarrow{0} \\
\overrightarrow{0} \\
\overline{0} \\
\overrightarrow{0} \\
.\end{array}$ & 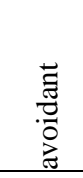 & 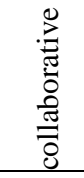 & 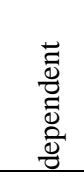 & 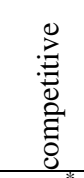 & 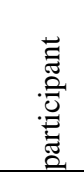 \\
\hline \multirow{3}{*}{ online } & \multirow{3}{*}{$\begin{array}{l}\text { academic } \\
\text { achievement } \\
\text { (post-test) }\end{array}$} & Pearson Correlation &, 216 &,- 195 &,- 099 & ,097 & $393^{*}$ & ,232 \\
\hline & & Sig. (2-tailed) & 279 & ,329 & ,622 & ,632 & ,043 & ,244 \\
\hline & & $\mathrm{N}$ & 27 & 27 & 27 & 27 & 27 & 27 \\
\hline \multirow[t]{3}{*}{ in-class } & \multirow{3}{*}{$\begin{array}{l}\text { academic } \\
\text { achievement } \\
\text { (post-test) }\end{array}$} & Pearson Correlation &, 152 & ,071 &,- 036 &,- 139 & , 109 &,- 153 \\
\hline & & Sig. (2-tailed) & 268 & 609 & ,795 & ,313 & ,428 & ,264 \\
\hline & & $\mathrm{N}$ & 55 & 55 & 55 & 55 & 55 & 55 \\
\hline
\end{tabular}

A paired sample t-test was conducted to evaluate whether a statistically significant difference existed between the means of academic achievement scores before and after intervention. The test was run separately for the online students (table 3) and separately for the in-class students (table 4). Assumption testing indicated no violation of assumptions in either of the groups (in-class and online).

Table 3

Paired Samples Test for online students

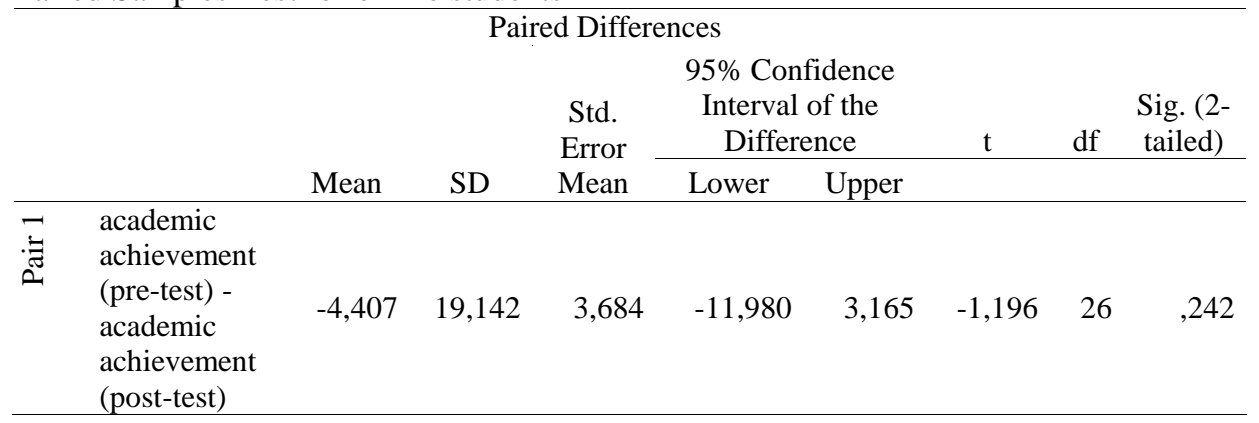

International Journal of Instruction, July $2018 \bullet$ Vol.11, No.3 
Table 4

Paired Samples Test for online students

\begin{tabular}{|c|c|c|c|c|c|c|c|c|c|}
\hline & \multicolumn{5}{|c|}{ Paired Differences } & \multirow{3}{*}{$\mathrm{t}$} & \multirow{3}{*}{$\mathrm{df}$} & \multirow{3}{*}{$\begin{array}{l}\text { Sig. (2- } \\
\text { tailed) }\end{array}$} \\
\hline & & \multirow[b]{2}{*}{ Mean } & \multirow[b]{2}{*}{ SD } & \multirow{2}{*}{$\begin{array}{l}\text { Std. } \\
\text { Error } \\
\text { Mean }\end{array}$} & \multicolumn{2}{|c|}{$\begin{array}{l}\text { 95\% Confidence } \\
\text { Interval of the } \\
\text { Difference }\end{array}$} & & & \\
\hline & & & & & Lower & Upper & & & \\
\hline ت. & $\begin{array}{l}\text { academic } \\
\text { achievement } \\
\text { (pre-test) - } \\
\text { academic } \\
\text { achievement } \\
\text { (post-test) }\end{array}$ & $-1,364$ & 15,588 & 2,102 & $-5,578$ & 2,850 &,- 649 & 54 & ,519 \\
\hline
\end{tabular}

\section{Limitations}

Several limitations are apparent with the present study. The size sample was relatively small. The cohort was limited to final year pre-service English major teachers taking Methodology course and they study at the same university what might have influenced the study results. The results would also be more precise if the academic performance was not categorised but applied as a continuous variable.

\section{DISCUSSION}

The main aim of this study was to a) find out whether there are differences in learning styles between those who prefer online and in-class schooling, b) to determine whether learning style influences academic achievement and to find out whether learning styles of students and the form of teaching generate interaction effects on their learning achievements.

The results of GRSLSS show (see graph 1 above) that in the in-class group the highest score was gained in the collaborative (3.97), independent and participant style $(3,62)$. In the group of online students, the highest score was reached in the category independent learner. The lowest scores were gained in the category of avoidant in the group of inclass students and in the group of online students it was the competitive learning style (1.98). After defining the dominant styles,we found there was not a student with the dominant competitive learning style. The distribution of students according to their learning style and the form they enrolled is presented in the following table. 
Table 5

Frequency of students according to learning styles and form

\begin{tabular}{|c|c|c|c|c|c|c|}
\hline \multirow[t]{2}{*}{ form } & & & Frequency & Percent & Valid Percent & Cumulative Percent \\
\hline & \multirow[t]{6}{*}{ Valid } & independent & 8 & 29,6 & 29,6 & 29,6 \\
\hline \multirow{5}{*}{$\stackrel{\mathscr{\Xi}}{\Xi}$} & & avoidant & 6 & 22,2 & 22,2 & 51,9 \\
\hline & & collaborative & 10 & 37,0 & 37,0 & 88,9 \\
\hline & & dependent & 2 & 7,4 & 7,4 & 96,3 \\
\hline & & participant & 1 & 3,7 & 3,7 & 100,0 \\
\hline & & Total & 27 & 100,0 & 100,0 & \\
\hline \multirow{6}{*}{ 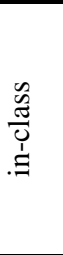 } & \multirow[t]{6}{*}{ Valid } & independent & 12 & 21,8 & 21,8 & 21,8 \\
\hline & & avoidant & 5 & 9,1 & 9,1 & 30,9 \\
\hline & & collaborative & 34 & 61,8 & 61,8 & 92,7 \\
\hline & & dependent & 1 & 1,8 & 1,8 & 94,5 \\
\hline & & participant & 3 & 5,5 & 5,5 & 100,0 \\
\hline & & Total & 55 & 100,0 & 100,0 & \\
\hline
\end{tabular}

The highest number of students in both, online and in-class groups have a dominant collaborative learning style. All subjects in sample are teacher trainees and they are prepared to be teachers. We may assume that it was their own decision to become teachers and the teachers mission is also to share the knowledge, skills, to collaborate.

As to the learning styles from the data in Table 1 and 2 it is apparent that there was relation observed between the form and learning styles (avoidant, participant, competitive and collaborative). Comparing the results with those of Diaz \&Cartnal's research (1999) we can see that the results concerning learning style and selection of the form completely differ. They found statistical significance in categories dependent and independent, while our research did not find it. On the contrary, we found the difference in the other 4 categories. There are several possible explanations - the change and development of the tools applied in 1999 and nowadays, the fact learners and teachers had worked together for two semesters before the intervention and thus knew each other well, same field of study may be also one of the factors that influenced the result. As to the academic performance, generally, no differences were observed what corresponds to the findings of Lu et al. (2003) who studied similar size sample and found there was no significant impact of learning style, gender, age on performance. Similarly, Wilkinson et al. (2014) summarised that although learning styles vary, they have no or little effect on academic performance.

The results of the two-way ANOVA (see Table 1) indicated that the interaction between learning style and academic achievement was not significant, $F(4,72)=.06, p>.05$. The confirmation of hypothesis $\mathrm{H} 02$ (Students with different learning styles do not statistically significantly differ in their academic performance based on the form of their study) is in line with the findings of Yazici (2017), Ishak, etal. (2017), Ahmad, et al. (2014) which found no significant difference between academic achievement by learning styles. 
No interaction effect was also observed for the form and academic achievement, $\mathrm{F}(1$, 72 ) $=.27, \mathrm{p}>.05$. This confirmed the Hypothesis 03 (In-class and online students do not statistically significantly differ in their academic performance). The finding is consistent with that of Means, et al. (2009). They published results of meta-analysis that studied research literature from 1996 through July 2008. Two of the criteria for text selections were an online and in-class comparison and measurement of student learning outcomes. Comparing purely online and in-class instruction they found a mean effect of $+0.14, p<$ .05. The authors compared their results to the previous summaries of distance learning (pre-Internet studies) and state that most of them (previous summaries) "concluded that learning at a distance is as effective as classroom instruction but no better" (ibid, p.18).

A paired sample t-test was also conducted to evaluate whether a statistically significant difference existed between the academic achievement scores before and after intervention in the online and in-class groups.n both groups we observed an increase (not statistically significant). The average score of the pre-test in the online group was 76,70 and 81,11 in the post test, what means 4,41 increase in the post-test. In the inclass group we recorded slightly lower increase in the post-test $(1,36)$ with the mean score 79,42 in the pre-test and 80,78 in the post-test.

No difference in academic performance observed in in-class or online course can be a signal that some courses can be offered in alternative forms or can be done in either of the forms with the same results.

The interaction effect hypothesis (H01: Students with different learning styles do not statistically significantly differ in their academic performance based on the form of their study) was accepted.

\section{CONCLUSION}

The current study investigated the effects of learning style and form on the academic achievement. The major findings are as follows: (a) learning styles have no significant effect on academic achievement; (b) form of teaching has no significant effect on academic achievement; and (c) students with different learning styles do not statistically significantly differ in their academic performance based on the form of their study.

Overall, these results indicate that rapid and constant development of the online tools enables the teachers to use virtual learning environments to successfully use them as possible alternative of the face-to-face classes. Still, teachers have to realise that the position and role of the teachers in online courses slightly differs if compared to the face-to-face teaching. The information about the dominant collaborative learning style in a group of pre-service teachers can be further studied as this may influence the way of developing skill and knowledge gain. Further studies, which take these variables into account, will need to be undertaken to investigate learning styles and performance in different situations with different cohort in VLE.

\section{Acknowledgement}

This article is a partial outcome of the research project KEGA 065PU-4/2016. 


\section{REFERENCES}

Ahmad, S., Safee, S., \&Afthanorhan, W. M. (2014). Learning styles towards mathematics achievements among higher education students. Global Journal of Mathematical Analysis,2(2). doi:10.14419/gjma.v2i2.2267

Amira, R., \&Jelas, Z. M. (2010). Teaching and Learning Styles in Higher Education Institutions: Do They Match? Procedia - Social and Behavioral Sciences, 7, 680-684. doi:10.1016/j.sbspro.2010.10.092

Benson, R., \&Brack, Ch. (2010). Online learning and assessment in higher education: a planning guide. Oxford: Chandos Publishing

Briggs, J. (2011.). Enhancing Learning. In Sternberg, R. J., \& Zhang, L. (Eds.), Perspectives on Thinking, Learning, and Cognitive Styles (pp. 73-102). New York: Routlege.

Chen, C.; Chiu, P., \& Huang, Y. (2015). The Learning Style-Based Adaptive Learning System Architecture. International Journal of Online Pedagogy and Course Design,5(2), 1-10. doi:10.4018/ijopcd.2015040101

Chickering, A. W., \&Gamson, Z. F. (1989). Seven principles for good practice in undergraduate education. Biochemical Education,17(3), 140-141. doi:10.1016/03074412(89)90094-0

Coffield, F.; Moseley, D.; Hall, E., \& Ecclestone, K. (2004). Learning styles and pedagogy in post-16 learning: a systematic and critical review. LSRC reference, Learning \& Skills Research Centre, London. Retrieved on October 10, 2017 from www.voced.edu.au/content/ngv\%3A13692

Conrad, R., \& Donaldson, J. A. (2004). Engaging the online learner: activities and resources for creative instruction. San Francisco, CA: Jossey-Bass.

Diaz, D. P., \& Cartnal, R. B. (1999). Students Learning Styles in Two Classes: Online Distance Learning and Equivalent On-Campus. College Teaching,47(4), 130-135. doi:10.1080/87567559909595802

Dille, B., \&Mezack, M. (1991). Identifying predictors of high risk among community college telecourse students. American Journal of Distance Education,5(1), 24-35. doi:10.1080/08923649109526729

Entwistle, N., McCune, V. and Walker, P. (2001) Conceptions, styles and approaches within higher education: Analytic abstractions and everyday experience. In Sternberg, R. J., \& Zhang, L. Perspectives on Thinking, Learning, and Cognitive Styles. (pp.103-136) London, Lawrence Erlbaum.

Fleming, N. D., \& Mills, C. (1992). Not Another Inventory, Rather a Catalyst for Reflection. To Improve the Academy,11(1), 137-155. doi:10.1002/j.23344822.1992.tb00213.x 
Fleming, S., Mckee, G., \& Huntley-Moore, S. (2011). Undergraduate nursing students learning styles: A longitudinal study. Nurse Education Today,31(5), 444-449. doi:10.1016/j.nedt.2010.08.005

Gardner, H. (2011). Frames of mind: the theory of multiple intelligences. New York, NY: Basic Books.

Grasha, A. F. (2002). Teaching with style: a practical guide to enhancing learning by understanding teaching and learning styles. Pittsburgh: Alliance Publ.

Halili, S. H.; Naimie, Z.; Siraj, S.; Ahmedabuzaid, R., \&Leng, C. H. (2014). Learning Styles and Gender Differences of USM Distance Learners. Procedia - Social and Behavioral Sciences, 141, 1369-1372. doi:10.1016/j.sbspro.2014.05.236

Hamidah, J. S.; Sarina, M. N., \&Jusoff, K. (2009). The Social Interaction Learning Styles of Science and Social Science Students. Asian Social Science,5(7). doi:10.5539/ass.v5n7p58

Ishak, N. B., \&Awang, M. M. (2017). The Relationship of Student Learning Styles and Achievement in History Subject. The International Journal of Social Sciences and Humanities Invention. doi:10.18535/ijsshi/v4i3.04

Kaminski, D. A., Théroux, P. J., Lister, B. C., \& Gabriele, G. A. (2005). Exploring the Link Between Student Learning Styles \& Grades in an Introductory Thermal-Fluids Course. In Proceedings of the 2005 American Society for Engineering Education Annual Conference \& Exposition (pp. 10.508.1-10.508.16). American Society for Engineering Education

Kamuche, F. U. (2011). Do Learning \& Teaching Styles Affect Students Performance? An Empirical Study. Journal of Business \& Economics Research (JBER),3(9). doi:10.19030/jber.v3i9.2806

Kolb, D. A. (2015). Experiential learning: experience as the source of learning and development. Upper Saddle River, NJ: Pearson Education, Inc.

Lehman, R. M., \&Conceição, S. C. O. (2010). Creating a sense of presence in online teaching: how to "be there" for distance learners. San Francisco: Jossey-Bass.

MacKenzie, L., \& Ballard, K. (2012). Can Using Individual Online Interactive Activities Enhance Exam Results? MERLOT Journal of Online Learning and Teaching,11(2), 262-266. Retrieved October 31, 2017 from http://jolt.merlot.org/Vol11no2/Ballard_0615.pdf

Mayer, R. E., \& Chandler, P. (2001). When learning is just a click away: Does simple user interaction foster deeper understanding of multimedia messages? Journal of Educational Psychology,93(2), 390-397. doi:10.1037//0022-0663.93.2.390

Means, B., Toyama, Y., Murphy, R., Bakia, M., \& Jones, K. (2009). Evaluation of evidence based practices in online learning: a meta analysis and review of online learning studies. Washington D.C.: U.S Department of Education. 
Nguyen, T. (2015). The Effectiveness of Online Learning:Beyond No Significant Difference and Future Horizons. MERLOT Journal of Online Learning and Teaching,11(2), 309-319. Retrieved October 31, 2017 from http://jolt.merlot.org/Vol11no2/Nguyen_0615.pdf

Palloff, R. M., \& Pratt, K. (2007). Building Online Learning Communities: Effective Strategies for the Virtual Classroom. Jossey Bass Inc.

Prensky, M. (2010). Teaching digital natives: partnering for real learning. Thousand Oaks: Corwin Press.

Prextová, T. (2016). Adaptation of Testing: Yes or No? In Novotná, J., \&Jančařík, A. (Eds.), ECEL 2016 - Proceedings of the 15th European Conference on e-Learning, (pp. 562-569). Reading, UK: Academic Conferences and Publishing International

Riechmann, S. W., \&Grasha, A. F. (1974). A Rational Approach to Developing and Assessing the Construct Validity of a Student Learning Style Scales Instrument. The Journal of Psychology,87(2), 213-223. doi:10.1080/00223980.1974.9915693

Russell, D. (2010). Cases on collaboration in virtual learning environments: processes and interactions. Hershey, PA: Information Science Reference.

Salmon, G. (2004). E-moderating: The Key to Teaching and Learning Online. Taylor \& Francis e-Library: London.

Sternberg, R. J., \& Zhang, L. (Eds.) (2011). Perspectives on Thinking, Learning, and Cognitive Styles. New York: Routlege.

Tsai, C. (2011). Achieving Effective Learning Effects in the Blended Course: A Combined Approach of Online Self-Regulated Learning and Collaborative Learning with Initiation. Cyberpsychology, Behavior, and Social Networking, 14(9), 505-510. doi:10.1089/cyber.2010.0388

Watts, N. (2010). Reflecting On Models for Online Learning in Theory \& Practice. AISHE-J, 2(1), 19.1-19.12, Retrieved January 10, 2016 from journals.sfu.ca/aishe/index.php/aishe-j/article/download/19/27

Weller, M. (2007). Virtual learning environments: using, choosing and developing your VLE. London: Routledge.

Wilkinson, T.; Boohan, M., \& Stevenson, M. (2013). Does learning style influence academic performance in different forms of assessment? Journal of Anatomy,224(3), 304-308. doi:10.1111/joa.12126

Yazic1, K. (2017). The Relationship between Learning Style, Test Anxiety and Academic Achievement. Universal Journal of Educational Research,5(1), 61-71. doi:10.13189/ujer.2017.050108

York, C. S., \& Richardson, J. C. (2012). Interpersonal Interaction in Online Learning: Experienced Online Instructors Perceptions of Influencing Factors. Online Learning,16(4). doi:10.24059/olj.v16i4.229. 